\title{
1 RELATING EDIACARAN FRONDS
}

2 T. Alexander Dececchi *, Guy M. Narbonne, Carolyn Greentree, and Marc

3 Laflamme

4 T. Alexander Dececchi* and Guy M. Narbonne, Department of Geological Sciences

5 and Geological Engineering, Kingston, Queen's University, Ontario, K7L 3N6, Canada.

6 E-mail: $\underline{\text { td50@queensu.ca, narbonne@queensu.ca. }}$

7 Carolyn Greentree, School of Earth, Atmosphere and Environment, Monash

8 University, Clayton, Victoria, 3800, Australia. Email cgreeentr@yahoo.co.uk.

9 Marc Laflamme. Department of Chemical and Physical Sciences, University of

10 Toronto, Mississauga, 3359 Mississauga Road, Mississauga, Ontario, L5L 1C6,

11 Canada. E-mail: marc.laflamme@utoronto.ca.

13 Abstract

14 Ediacaran fronds are key components of terminal-Proterozoic ecosystems. They

15 represent one of the most widespread and common body forms ranging across all

16 major Ediacaran fossil localities and time slices postdating the Gaskiers glaciation,

17 but uncertainty over their phylogenetic affinities has led to uncertainty over issues

18 of homology and functional morphology between, and within, organisms displaying

19 this ecomorphology. Here we present the first large scale, multi-group cladistic

20 analysis of Ediacaran organisms, sampling 20 ingroup taxa with previously asserted

21 affinities to the Arboreomorpha, Erniettomorpha and Rangeomorpha. Using a newly

22 derived morphological character matrix that incorporates multiple axes of potential

23 phylogenetically informative data, including architectural, developmental, and

24 structural qualities, we seek to illuminate the evolutionary history of these

25 organisms. We find strong support for existing classification schema and devise

26 apomorphy-based definitions for each of the three frondose clades examined here.

27 Through a rigorous cladistics framework it is possible to discern the pattern of 
evolution within, and between, these clades, including the identification of

29 homoplasies and functional constraints. This work both validates earlier studies of

30 Ediacaran groups and accentuates instances where previous assumptions of their

31 natural history are uninformative.

\section{Introduction}

34 The Ediacara biota is an assemblage of organisms from the late Ediacaran Period

35 (571-541 Ma; Pu et al., 2016) that represents the world's oldest abundant and

36 globally distributed fossils of architecturally complex, megascopic organisms

37 (Narbonne 2005; Fedonkin et al. 2007; Xiao and Laflamme 2009; Erwin et al. 2011).

38 These soft-bodied organisms are typically preserved as impressions, primarily on

39 the bottom surfaces of event beds of sandstone or volcanic ash (Narbonne 2005:

40 Kenchington and Wilby 2014), or less commonly within event beds (Grazhdankin

41 and Seilacher 2002; Narbonne et al. 2009, 2014; Vickers-Rich et al. 2013; Ivantsov et

42 al. 2016), with multiple individuals revealing minute, millimetre-scale detail of their

43 external morphology. These fossils capture a disparity of body form and diversity of

44 functions that belies their deceptively simplistic morphology (Erwin et al. 2011,

45 Laflamme et al. 2013). The relatively low diversity coupled with high morphological

46 disparity (Erwin et al. 2011) and a large number of monospecific genera (Fedonkin

47 et al. 2007) lead to difficulties in isolating any visible hierarchy in the morphology,

48 and disagreements concerning homology statements between groupings (e.g.

49 compare Laflamme et al. 2013 with Budd and Jensen, 2015).

51 The Ediacara biota immediately preceded the Cambrian 'explosion' of animal

52 diversity (Erwin and Valentine 2013) and thus occupied a pivotal position in the

53 early evolution of complex life. While metazoan taxa were present, including the

54 purported stem-group mollusc Kimberella (Fedonkin and Waggoner 1997), they

55 coexisted alongside organisms whose affinities and relationships to any living phyla

56 remain unknown and controversial (Erwin et al. 2011; Droser and Gehling 2015;

57 Darroch et al. 2015). These uncertainties have hindered attempts to integrate these

58 fossils into a broad-scale understanding of Neoproterozoic and Cambrian evolution 
59 (Erwin et al. 2011). Current classifications methods involve controversial linkages

60 between Ediacaran taxa based on morphological similarity of a small number of key

61 features (Erwin et al. 2011) without any means of testing whether these characters

62 are actually phylogenetically informative. In a significant overview of metazoan

63 ancestry, Budd and Jensen (2015) noted this lack of rigorously defined clade-

64 specific autapomorphies and tested synapomorphies for any previously proposed

65 Ediacaran clades. They argued that, in the absence of autapomorphically-defined

66 clades, it is impossible to make informed assertions about homology and homoplasy

67 in the Ediacara biota, and that any understanding of these organisms is

68 correspondingly reduced.

70 These difficulties can be minimized by defining Ediacaran clades through uniquely

71 derived traits (autapomorphies), similar to other branches of fossil and extant life.

72 Previous attempts to cladistically define the specific groups within the Ediacara

73 biota have been met with limitations - either in terms of alpha diversity studied or

74 temporal and geographic ranges used (Brasier and Antcliffe 2009) - or have mapped

75 characters associated with individual Ediacaran taxa onto existing metazoan

76 molecular phylogenies (Gold et al. 2015). Major organizational systems within, and

77 between, groups of Ediacaran organisms have often been based on competing

78 classification schemes that, at times, highlight specific a priori assumptions of how

79 these organisms lived and grew (Pflug 1972; Narbonne 2004,; Erwin et al. 2011;

80 Brasier et al. 2012; Grazhdankin 2014). These previous groupings may be biased by

81 features that are likely highly homoplastic (Laflamme and Narbonne 2008) and have

82 led to interpretations of the Ediacara biota in terms of functional analogs

83 irrespective of phylogeny (Droser and Gehling 2015).

84

85 The present study represents the first analysis to propose autapomorphically-

86 defined Ediacaran clades identified by modern cladistic methods. Previous work has

87 focused on using selected features of assumed greater evolutionary significance or

88 general similarity of form to group organisms. This leaves open the possibility for

89 convergence or mistaken homology assertion to artificially grouped organisms, 
90 which has led to the suggestion that our knowledge of the evolutionary history of

91 these organisms is still at an early stage (Budd and Jensen 2015). Here we seek to

92 create a chain of common ancestry linking organisms together using a character-

93 based system to identify shared derived features and not a priori assumptions of

94 trait importance. For the present study we focus on taxa from three purported

95 Ediacaran groups previously recognized on the basis of morphology

96 (Rangeomorpha, Erniettomorpha, and Arboreomorpha; see Laflamme and

97 Narbonne 2008; Erwin et al. 2011; note that Grazhdankin 2014 recognizes similar

98 taxonomic groups under different names), which we chose for our analysis because

99 they are widespread, abundant, and occur through a significant time range.

\section{Methods}

102 Our study aims to identify clade-level relationships and establish a series of strong

103 synapomorphy-based definitions for each group. All ingroup taxa used herein have

104 previously been assigned to one of three distinct groupings (Erwin et al. 2011): the

105 Rangeomorpha, the Erniettomorpha, or the Arboreomorpha. We included the

106 majority of named and described members, minimally at the genus level, that are

107 currently accepted in each of the major groupings (Table 1). Analysis within these

108 groups was restricted to named taxa that are well described in the literature on the

109 basis of multiple, well-preserved specimens. Our analysis includes all frondose and

110 non-frondose taxa within these three groups that meet these criteria, thus providing

111 critical insights into expressions of homology and homoplasy in the Ediacara biota,

112 and encompasses the temporal, geographic, and bathymetric ranges for each of the

113 reported groups (Narbonne 2005; Boag et al. 2016). We did not synonymize the taxa

114 based on a single criterion for character generation as our dataset encompasses

115 multiple axes of variation, such as morphometric, growth patterning and branching

116 architecture, in an effort to encapsulate all the evolutionary relevant information in

117 these organisms.

118

119 Due to the relative morphological simplicity (compared to the majority of

120 metazoans) of the organisms investigated here, and their uncertain relationship to 
121 later clades, we chose not to use existing metazoan-based morphological character

122 sets as the basis for this work. A novel dataset consisting of 22 morphological

123 characters (Supplementary Table 1; Supplementary Figure 1) was constructed from

124 descriptions and illustrations in the literature supplemented by our personal

125 examination of multiple specimens, including the holotypes for all of the taxa except

126 for the recently named Charniodiscus yorgensis (Ivantsov 2016).

128 Characters were sampled from all regions of the organisms, and were specifically

129 chosen to avoid restating of previously proposed diagnostic features for a group

130 (e.g. Laflamme and Narbonne 2008). Instead, we critically examined all structural

131 features and decomposed them into their constituent parts. Beyond guiding our

132 taxonomic selection, existing classification schemes had no impact on the coding of

133 morphological features or our analysis of these features. We added new characters

134 and character states to document all sources of variation to ensure our dataset was

135 as encompassing as possible. These include characters of the holdfast beyond its

136 presence or absence, in particular its position relative to the sediment-water

137 interface; see Burzynski and Narbonne (2015) for a discussion on differentiation of

138 this feature. This combination of new characters and detailed dissection of

139 previously suggested significant features allows us to test of existing classification

140 schemes and to evaluate the validity of existing diagnostic morphologies.

142 Characters were further defined to avoid oversplitting by focusing on key aspects

143 that are functionally independent of each other. This is pivotal because a high

144 degree of character dependence violates a key assumption of cladistic analyses by

145 overweighting the strength of observed relationships (O'Keefe and Wagner 2001).

146 For example the modularly-repeating "rangeomorph element" (Narbonne 2004)

147 was decomposed into four new characters that address the presence/absence of

148 modularity, the branching nature of the element, the shape of elements that

149 compose the petalodium, and whether those elements are self-similar and repeated

150 at multiple scales. Each of these characters, and the states within them, are potential

151 independent sources of phylogenetic information that are subsumed in the simple 
152 statement of presence/ absence of a rangeomorph element (e.g. Narbonne 2004;

153 Laflamme and Narbonne 2008). The taxa examined here show several permutations

154 of these four characters and their states (e.g. the modular, non-branching, tubular

155 and non-fractal patterns in Erniettomorphs vs. the non-modular, branching but non-

156 fractal pattern seen in Charniodiscus) (Supplementary Table 2). Splitting the

157 "rangeomorph element" into its constituent parts further permits the scoring of

158 potential intermediate morphologies (i.e. a non-modular, non-tubular, branching

159 frond with some fractal elements) that are currently unknown.

160

161 A potential influencing factor on the understanding in larger trends with these

162 organisms is the challenge in selection of the outgroup. We chose the purported

163 cnidarian Thaumaptilon (Conway-Morris 1993) from the Burgess Shale (Cambrian)

164 as the outgroup for our analysis. Thaumaptilon is well illustrated and characterized,

165 and shares a similar body plan to Ediacaran fronds, but is believed to represent a

166 distinct evolutionary lineage (Antcliffe and Brasier 2007, Laflamme and Narbonne

167 2008). Furthermore, we also ran the analysis using an artificially generated

168 outgroup based on an undifferentiated yet non-modular frond without stem or

169 holdfast. All phylogenetic investigations were done using heuristic search algorithm

170 with default settings in PAUP v. 4.0 (Swafford 2003). Bootstrap support, which is

171 resampling with replacement of the character set to investigate the strength of the

172 signal, and Bremier decay indices, which denotes the number of extra steps need to

173 collapse a node of interest, were taken as measures of nodal support. For

174 bootstrapping analysis 100 replications were done with the 100000 trees kept per

175 replication and only nodes above $50 \%$ support retained.

176

177 Results

178 Heuristic search of the complete dataset (Figure 1) resulted in 12 most

179 parsimonious trees of length 49 with a consistency index of 0.673 (where 1.0

180 indicates no homoplasy of characters across the tree). Furthermore, a retention

181 index denoting the character fit and proportion of informative states was high 
182 (0.83). From the trees, it was possible to assign autapomorphies that define each 183 clade.

185 We find strong support for the Rangeomorpha, Arboreomorpha and Erniettomorpha 186 clades, whose membership mimics those proposed by Erwin et al. (2011), and a 187 sister relationship between Rangeomorpha and Erniettomorpha. Arboreomorpha 188 can be defined by their secondary branches that are spherical or hemispherical in 189 shape, with no lower subdivisions present. They also display differentiation along 190 the coronal plane (i.e. the plane that subdivides the petalodium into a back/front or 191 dorsal/ventral) and the lack of a modular petalodium, though this is also present in

192 Thaumaptilon. The Rangeomorpha-Erniettomorpha clade is defined by having a 193 petalodium composed of modular elements that do not show any differentiation in 194 the coronal plane. Rangeomorpha, the most diverse and disparate of the three 195 clades investigated, is defined by having a petalodium composed of branching, 196 modular elements that display self-similar (fractal) morphology. Our analyses 197 suggest that the ancestral condition was a single-sided petalodium, though the 198 majority of taxa displaying this condition may be biasing this. Erniettomorphs are 199 defined as having petalodia composed of undifferentiated, non-repeating tubular 200 modular elements that are uniform in width. The unique "bag shaped" morphology 201 of Ernietta is derived from the fusion of the two petaloids at their edge as marked by 202 a major suture (Ivantsov et al. 2016), and we scored this as such even though the 203 petaloids do not form a single, flat plane as seen in most other fronds.

205 The consensus tree presents a semi-resolved topology that broadly supports 206 previous subdivisions within the Rangeomorpha, identifying a clear separation 207 between single-sided and tightly constrained (undisplayed per Brasier et al. 2012) 208 "charnids" (Vinlandia, Charnia) and the double-sided primary and secondary 209 branching (displayed and unfurled per Brasier et al. 2012) "rangids" (Rangea, 210 Fractofusus, Bradgatia). Beothukis, Culmofrons and Trepassia are found notably 211 outside the "charnid" subgrouping, forming possible transitional steps uniting the

212 "charnids" with the "rangids". Our whole-fossil analysis of Beothukis and Culmofrons 
213 does not support the recent suggestion that the two taxa may be synonymous at the 214 genus level (Liu et al. 2016). Within the Erniettomorpha, Ernietta and Pteridinium

215 form a sister relationship to the exclusion of Swartpuntia, though this may be due to

216 the latter having a more classical "frond" appearance including the presence of a

217 stem and stalk. There is little resolution within the Arboreomorpha, which reflects

218 the general similarity of all species in this clade and suggests that the alpha

219 taxonomy of this clade requires more granular traits, such as segment count and

220 frond shape (Laflamme et al. 2004), that are not appropriate for beta taxonomic

221 level analyses such as this.

222

\section{Discussion}

224 Focusing on a subset of Ediacaran taxa with a similar gross body plan ("fronds"), but 225 with significant structural and architectural variation, avoids the issue of character 226 inflation without adding resolution. Incorporating all 10 proposed groups from 227 Erwin et al. (2011) would have required a character set that was unscorable across 228 much of the taxon set. While missing data itself is not necessarily a hindrance to 229 phylogenetic analyses (Wiens and Morrill 2011), it is the nature of how that missing 230 data is distributed that would be of concern (Wiens 2003). If the data is randomly 231 distributed (i.e. it most columns are partially scored by taxa across the matrix), 232 more characters (even if only partially scored) aid in phylogenetic resolution.

233 However, this is not the case if the data is clustered into non-overlapping partitions

234 (i.e. most columns are empty; Wiens 2003) as found in an Ediacara biota wide

235 analysis. As such, the amount of missing data is not as troubling as the distribution of 236 the missing data.

238 Another possible challenge for this taxon set is whether there is enough discernable 239 morphology to create the valid characters and states necessary to establish a well240 supported evolutionary tree. While large datasets are not a prerequisite (Simões et 241 al. 2016), lower quantities of data limit resolution power (Bremer et al. 1999). Our 242 results show that there is enough distinct morphological data among Ediacaran 
243 fronds to generate a viable phylogenetic signal, even given our limited

244 understanding of multiple aspects of the biology and physiology of these organisms.

246 Fronds such as Charnia, Charniodiscus, and Rangea are abundant in Ediacaran

247 assemblages worldwide, and provide some of the most iconic images of the Ediacara

248 biota. Early workers viewed the frondose morphology as representing a major

249 division in Ediacaran taxonomy (Glaessner 1979) but this has fallen out of favor as

250 subsequent studies have increasingly concluded that Ediacaran fronds are

251 polyphyletic (Laflamme and Narbonne 2008; Erwin et al. 2011; Grazhdankin 2014).

252 Our cladistic analysis confirms that Ediacaran fronds occur in multiple Ediacaran

253 clades, two of which (Erniettomorpha and Rangeomorpha) also contain non-

254 frondose taxa. This supports the view that fronds are an ecomorph bauplan, (i.e.

255 taxa that are similar in morphology due to similar niche usage but may not be

256 closely related phylogenetically; see Williams 1972), found among unrelated

257 Ediacaran groups (Laflamme and Narbonne 2008). Our whole-organism analysis

258 finds strong support for the three groupings (Arboreomorpha, Erniettomorpha, and

259 Rangeomorpha) suggested by previous work based on major structural differences

260 in the components of the petalodium (Laflamme and Narbonne 2008; Erwin et al.

261 2011). Our study also provides a set of synapomorphies to define each clade (Figure

262 1, Table 2), building a framework to address issues of homology raised by Budd and 263 Jensen (2015).

265 The artificially generated outgroup allowed us to test the robustness of our primary 266 analysis topology (Figure 2). This run (120 most parsimonious trees of length 49, CI 2670.667 , RI 0.83) confirms the distinct nature of the three clades, though we find a 268 different interrelationship between them. There is a shift in the positioning of the 269 Arboreomorpha into a sister relationship with Rangeomorpha, uniting the two 270 predominately upright frondose clades. This topology further suggests that 271 modularity is homoplastic among frondose organisms. While these results are 272 intriguing we do not place significant weight to the resulting trees, beyond the 
273 confirmation of the distinctness of the three clades, due to the hypothetical nature of

274 this outgroup.

275

276 The precise and testable criteria used in constructing the evolutionary history of

277 each clade allows for detailed examination of major growth and evolutionary

278 patterning across these clades. One potential area of interest concerns growth

279 process - either through insertion or inflationary models (Brasier et al. 2012).

280 Growth by insertion implies that new branches are added throughout life, at either

281 or both poles, to increase the size of the organism. This is contrasted by inflationary

282 growth in which organisms attain their adult complement of sections/branches

283 early in ontogeny and subsequent growth involves enlargement of existing

284 sections/branches. We find preliminary support for an ancestral inflationary type of

285 growth, which could have significantly influenced multiple aspects of the organism's

286 biology and has been suspected to be a major discriminating factor in Ediacaran

287 phylogenetics (Antcliffe and Brasier 2007; Brasier et al. 2012). Differences in

288 growth strategy are also suspected to influence maximum size due to the need to

289 ensure a large surface area to volume ratio for effective osmotrophic feeding

290 (Laflamme et al. 2009). Both strategies (inflation vs. insertion) at either or both

291 poles have been reported in Erniettomorpha and Rangeomorpha (Grazdankin and

292 Seilacher 2002; Antcliffe and Brasier 2007; Gehling and Narbonne 2007; Laflamme

293 et al. 2009; Narbonne et al. 2009; Laflamme et al. 2012; Ivantsov et al. 2016) with

294 additive growth seen in the oldest-known Rangeomorpha Trepassia. It is of interest

295 that the terminal addition pattern is seen in charnids (Antcliffe and Brasier 2007)

296 and the erniettomorph Pteridinium. This pattern is similar to that reported in

297 several bilaterian groups as well as the enigmatic Ediacaran fossil Dickinsonia and

298 has been suggested to link them to basal Bilateria (Gold et al. 2015). The

299 identification that this feature is homoplastic and evolved at least 3 times across

300 Ediacaran groups urges caution in using growth strategies as a major classification

301 criteria in this area of the tree of life. Within the Arboreomorpha we do not see

302 variation in growth strategy, as all known taxa grew by branch inflation (Laflamme 
303 et al. 2004), with the number of branches a potential species-level diagnostic

304 feature.

305

306 Within the Rangeomorpha the presence of additive growth is seen in two separate 307 groups (Figure 1B), the derived "charnids" (Trepassia, Charnia) and the multifoliate 308 rangid Pectinifrons (Bamforth et al. 2008; Narbonne et al. 2009). This suggests 309 convergence of growth patterns between charnids and Pectinifrons, as Pectinifrons is 310 nested within a clade with multiple members displaying inflationary growth. While 311 it may at first seem unlikely that a major shift in growth strategy occurred multiple 312 times within a clade, we know that the evolution of growth by insertion has 313 occurred several times within eukaryotes (Gold et al. 2015). Furthermore, the exact 314 nature of how inflation occurs seems to differ between charnids and Pectinifrons, 315 implying that the developmental pathways may differ between the two. Pectinifrons 316 employs insertion for the addition of struts along the pedicle, which is then followed 317 by branch inflation for subsequent growth of primary branches (Bamforth et al. 318 2008). In contrasts, charnids appear to grow either exclusively by primary addition

319 (Trepassia) or by terminal primary addition with inflation of previously added 320 primaries (Charnia) (Narbonne et al. 2009). The insertion growth strategy seen in 321 Pectinifrons and charnids may be paedomorphic, as other rangids are suspected to 322 undergo branch addition to "adult" complement very early in ontogeny, with 323 inflationary growth model becoming dominant later in their life cycle (Gehling and 324 Narbonne 2007).

326 The linking of Erniettomorpha and Rangeomorpha as sister clades is notable, though 327 caution is advised due to the lack of resolution of this group using the artificially 328 generated outgroup (Figure 2). The proposed synapomorphies for this group 329 include the lack of differentiation in the coronal plane, and the modular construction 330 of their petalodia (or in the case of some Erniettomorpha, the entire organism). 331 Should the phylogeny prove valid, this may signal a common developmental system 332 or be convergent, related to how they obtained nutrients through osmotrophy 333 (Laflamme et al. 2009). While it is tempting to accept this clade at face value and 
334 suggest that the lowest level of rangeomorph branching (which can resemble a

335 tube) is homologous to the large tube of an erniettomorph, several factors suggest to

336 us that modularity may be homoplastic. First is the nature of the modular elements.

337 Within Erniettomorpha, the modules are uniform, tubular and possess no lower

338 level of differentiation, which sharply contrasts with the repeated branching of the

339 major elements in Rangeomorpha (Laflamme and Narbonne 2008) which may have

340 evolved to increase surface area as volume expands. Based on the results of this

341 study, modular construction (Narbonne 2004) appears to be a common

342 morphological adaptation among Ediacaran clades to increase body size (see the

343 discussion in Hoyal Cuthill and Conway Morris 2014), with little homology in its

344 developmental origins. The repeated evolution of modularization may be a function

345 of the limited genetic toolkit available to these organisms (Narbonne 2005; Hoyal

346 Cuthill and Conway Morris 2014).

\section{Conclusions}

350 Our cladistic analysis provides a clear and rigorously defined set of synapomorphies

351 to establish monophyletic clades of Ediacaran organisms. We find strongly

352 supported Rangeomorpha, Erniettomorpha and Arboreomorpha that correspond to

353 previously proposed groupings, lending strength to existing morpho-grouping

354 schemes. We also find that growth strategies seem to have been somewhat plastic

355 within these clades, as insertionary growth appears to have evolved multiple times

356 within the fronds. Finally, while our analysis produces a sister group relationship

357 between the Rangeomorpha and the Erniettomorpha, the convergence on a modular

358 body construction is not unique to these taxa and appears to have been widespread

359 across the Ediacara biota. This framework can be extended to incorporate other

360 members of the Ediacara biota such as the Dickinsoniomorpha and

361 Triradialomorpha, and thus bring Ediacaran fossils into the age of cladistics.

\section{Acknowledgements}


364 We are grateful for funding through a William White Fellowship to TAD, NSERC

365 Discovery Grants to GMN and ML, and a Queen's Research Chair to GMN. We also

366 thank C. Lablans and G. Burzynski for their help with photographing specimens and

367 helpful discussions. Critical comments by C. Kenchington and an anonymous reviewer

368 greatly improved the manuscript.

References

Antcliffe, J.B., and M.D. Brasier. 2007. Charnia and sea pens are poles apart. Journal of the Geological Society 164:49-51.

Bamforth, E.L., G. M. Narbonne, and M. Anderson. 2008. Growth and ecology of a multi-branched Ediacaran rangeomorph from the Mistaken Point assemblage, Newfoundland. Journal of Paleontology 82(4):763-777.

Boag, T. H., S. A. F. Darroch, and M. Laflamme. 2016. Ediacaran distributions in space and time: testing assemblage concepts of earliest macroscopic body fossils. Paleobiology 42(4):574-594.

Brasier, M.D., and J.B. Antcliffe. 2009. Evolutionary relationships within the Avalonian Ediacara biota: new insights from laser analysis. Journal of the Geological Society 166:363-384.

Brasier, M.D., J.B. Antcliffe, and A.G. Liu. 2012. The architecture of Ediacaran fronds. Palaeontology 55:1105-1124.

Bremer, B., R. K. Jansen, B. Oxelman, M. Backlund, H. Lantz, and K.-J. Kim. 1999. More Characters or More Taxa for a Robust Phylogeny-Case Study from the Coffee Family (Rubiaceae). Systematic Biology 48(3):413-435.

Budd, G. E., and S. Jensen. 2015. The origin of the animals and a 'Savannah' hypothesis for early bilaterian evolution. Biological Reviews doi: 10.1111/brv.12239

Burzynski, G. and G.M. Narbonne, 2015. The discs of Avalon: Relating discoid fossils to frondose organisms in the Ediacaran of Newfoundland, Canada. Palaeogeography, Palaeoclimatology, Palaeoecology, 434: 34-45.

Conway Morris, S. 1993. Ediacaran-like fossils in Cambrian Burgess Shale-type faunas of North America. Palaeontology, 36(3): 593-635.

Darroch, S. A. F., E. A. Sperling, T. H. Boag, R. A. Racicot, S. J. Mason, A. S. Morgan, S. Tweedt, P. Myrow, D. T. Johnston, D. H. Erwin, and M. Laflamme. 2015. Biotic replacement and mass extinction of the Ediacara biota. Proceedings of the Royal Society B-Biological Sciences 282(1814):129-138.

Droser, M. L., and J. G. Gehling. 2015. The advent of animals: The view from the Ediacaran. Proceedings of the National Academy of Sciences of the United States of America 112(16):4865-4870.

Erwin, D., M. Laflamme, S. Tweedt, E. Sperling, D. Pisani, and K. Peterson. 2011. The Cambrian Conundrum: Early Divergence and Later Ecological Success in the Early History of Animals. Science 334(6059):1091-1097. 
405

406

407

408

409

410

411

412

413

414

415

416

417

418

419

420

421

422

423

424

425

426

427

428

429

430

431

432

433

434

435

436

437

438

439

440

441

442

443

444

445

446

447

448

449

Erwin, D., and J. Valentine. 2013. The Cambrian explosion: the construction of animal biodiversity. Roberts and Company.

Fedonkin, M.A., J. G. Gehling, K. Grey, G. M. Narbonne, and P. Vickers-Rich. 2007. The Rise of Animals: Evolution and Diversification of the Kingdom Animalia. Johns Hopkins University Press, Baltimore.

Fedonkin, M.A., and B. Waggoner. 1997. The Late Precambrian fossil Kimberella is a mollusc-like bilaterian organism. Nature 388:868-871.

Gehling, J.G., and G.M. Narbonne. 2007. Spindle-shaped Ediacara fossils from the Mistaken Point assemblage, Avalon Zone, Newfoundland. Canadian Journal of Earth Sciences 44(3):367-387.

Glaessner, M.F. 1979. Biogeography and biostratigraphy: Precambrian. Pp. 79-118. In R.C. Moore, R. Robinson, C. Teichert, J. Keim, L. McCormick, and R. Williams, eds. Treatise on Invertebrate Paleontology, Part A, Introduction, Fossilization (Taphonomy), Biogeography and Biostratigraphy. Geological Society of America, Lawerence, Kansas.

Gold, D. A., B. Runnegar, J. G. Gehling, and D. K. Jacobs. 2015. Ancestral state reconstruction of ontogeny supports a bilaterian affinity for Dickinsonia. Evolution \& Development 17(6):315-324.

Grazhdankin, D.V. 2014. Patterns of evolution of the Ediacaran soft-bodied biota. Paleontology 45(1):57-78.

Grazhdankin, D.V. and A. Seilacher. 2002. Underground Vendobionta from Nambia. Journal of Paleontology 88(2):269-283.

Hoyal Cuthill, J. F., and S. Conway Morris. 2014. Fractal branching organizations of Ediacaran rangeomorph fronds reveal a lost Proterozoic body plan. Proceedings of the National Academy of Sciences 111(36):13122-13126.

Ivantsov, A. Y., G. M. Narbonne, P. W. Trusler, C. Greentree, and P. Vickers-Rich. 2016. Elucidating Ernietta: new insights from exceptional specimens in the Ediacaran of Namibia. Lethaia 49:540-554.

Ivantsov, A.Y. 2016. Reconstruction of Charniodiscus yorgensis (Macrobiota from the Vendian of the White Sea). Paleontological Journal. 50 (1): 1-12.

Kenchington, C. G., and P. Wilby. 2014. Of time and taphonomy: preservation in the Ediacaran. Pp. 101-122. In M. Laflamme, J. D. Schiffbauer, and S. A. F. Darroch, eds. Reading and Writing of the Fossil Record: Preservational Pathways to Exceptional Fossilization. Geological Society of America.

Laflamme, M., S. A. F. Darroch, S. M. Tweedt, K. J. Peterson, and D. H. Erwin. 2013. The end of the Ediacara biota: Extinction, biotic replacement, or Cheshire Cat? Gondwana Research 23(2):558-573.

Laflamme, M., L. Flude, and G. Narbonne. 2012. Ecological tiering and the evolution of a stem: The oldest stemmed frond from the Ediacaran of Newfoundland, Canada. Journal of Paleontology 86(2):193-200.

Laflamme, M., and G. Narbonne. 2008. Ediacaran fronds. Palaeogeography Palaeoclimatology Palaeoecology 258(3):162-179.

LaFlamme, M., G. Narbonne, and M. Anderson. 2004. Morphometric analysis of the Ediacaran frond Charniodiscus from the Mistaken Point Formation, Newfoundland. Journal of Paleontology 78(5):827-837. 
Laflamme, M., S. H. Xiao, and M. Kowalewski. 2009. Osmotrophy in modular Ediacara organisms. Proceedings of the National Academy of Sciences of the United States of America 106(34):14438-14443.

Liu , A.G., J.J. Matthews, and D. Mcllroy. 2016. The Beiothukis/Culmofrons problem and its bearing on Ediacaran macroossil taxonomy: Evidence from an exceptional new fossil locality. Palaeontology 59(1): 45-58.

Narbonne, G.M. 2004. Modular construction of early Ediacaran complex life forms. Science 305(5687):1141-1144.

Narbonne, G.M. 2005. The Ediacara biota: Neoproterozoic origin of animals and their ecosystems. Annual Review of Earth and Planetary Sciences 33:421442.

Narbonne, G., M. Laflamme, C. Greentree, and P. Trusler. 2009. Reconstructing a lost world: Ediacaran rangeomorphs from Spaniard's Bay, Newfoundland. . Journal of Paleontology 83(4):503-523.

Narbonne, G., M. Laflamme, P. Trusler, R.W. Dalrymple, and C. Greentree. 2014. Deep-water Ediacaran fossils from northwestern Canada: Taphonomy,ecology, and evolution. Journal of Paleontology 88(2):207-223.

O'Keefe, F. R., and P. J. Wagner. 2001. Inferring and testing hypotheses of cladistic character dependence by using character compatibility. Systematic Biology 50(5):657-675.

Pflug, H. 1972. Systematik der jung-präkambrischen Petalonamae Pflug 1970. Palaontologische Zeitschrift 46(1):56-67.

$\mathrm{Pu}$, J.P., Bowing, S.A., Ramezani, J., Myrow, P., Raub, T.D., Landing, E., Mills, A., Hodgin, E., and F.A. Macdonald. 2016. Dodging snowballs: Geochronology of the Gaskiers glaciation and the first appearance of the Ediacaran biota. Geology 44(11): 955-958.

Simões, T. R., M. W. Caldwell, A. Palci, and R. L. Nydam. 2016. Giant taxon-character matrices: quality of character constructions remains critical regardless of size. Cladistics doi:10.1111/cla.12163

Swafford, D. 2003. PAUP*. Phylogenetic analysis using parsimony (*and other methods). Version 4.0. Sinauer Associates, Sunderland, MA.

Vickers-Rich, P., A. Y. Ivantsov, P. Trusler, G.M.Narbonne, M.Hall, S.A.Wilson, C.Greentree, M.A. Fedonkin, D.A.Elliott, K.H.Hoffmann and G.I.C. Schneider. 2013. Reconstructing Rangea: New discoveries from the Ediacaran of southern Nambia. Journal of Paleontology 87(1):1-15.

Wiens, J. J. 2003. Missing Data, Incomplete Taxa, and Phylogenetic Accuracy. Systematic Biology 52(4):528-538.

Wiens, J. J., and M. C. Morrill. 2011. Missing Data in Phylogenetic Analysis: Reconciling Results from Simulations and Empirical Data. Systematic Biology 60(5):719-731.

Williams, E.E. 1972. The origins of faunas-evolution of lizard congeners in a complex island fauna: a trial analysis. Evolutionary Biology 6: 47-89.

Xiao, S., and M. Laflamme. 2009. On the eve of animal radiation: phylogeny, ecology and evolution of the Ediacara biota. Trends in Ecology \& Evolution 24(1):3140 . 


\section{Figure captions:}

Figure 1: Phylogeny of Ediacaran fronds using Thaumaptilion as the outgroup to polarize the data. A)Bootstrap consensus tree numbers by the node represent the Bremier support (above the branch) and bootstrap support (below the branch) for each node. B) Strict consensus tree.

Figure 2: Phylogeny of Ediacaran fronds using artifically generated outgroup to polarize the data. A)Strict consensus B) Majority rules consensus tree.

Supplementary Figure 1: Illustration of the morphological characters used in this analysis. The first number denotes the character followed by the state illustrated, see Supporting Table 1,2 for details. All characters and states are figured except Character 12 (Growth pattern). Taxa represented are: A) Charniodiscus arboreus; B) Avalofractus abalculus; C) Swartpuntia germsi; D) Charnia masoni; E) Pectinifrons abyssalis; F) Culmofrons plumosa; G)Ernietta plateauensis; H) Rangea schneiderhoehni; I) Beothukis mistakensis; J) Fractofusus misrai specimen that is overfolded showing both the dorsal and ventral planes and K) Charniodiscus arboreus specimen overfloded showing differences in coronal plane. The reconstruction of Rangea is modified from Vickers-Rich et al. (2013, Fig. 9).

\section{Table captions:}

Table 1: Taxon list and preliminary group identification based on the literature for 21 terminal taxa examined for this study.

Table 2: Synapomorphies listed in terms of character (state) for the three major clades using both Thaumaptilion (A) and artificially generated outgroup (B) analyses. We should note the difference between unambiguous and ambiguous synapomorphies is dependant on the resolution of the node preceding that of interest. As selection of outgroup alters the sister clade relationships (see Figure 1 and 2) we suggest using only the unambiguous synapomorphies list is an overly conservative estimate of the number of apomorphies per clade.

Supplementary Table 1: Character list.

Supplementary Table 2: Character matrix 


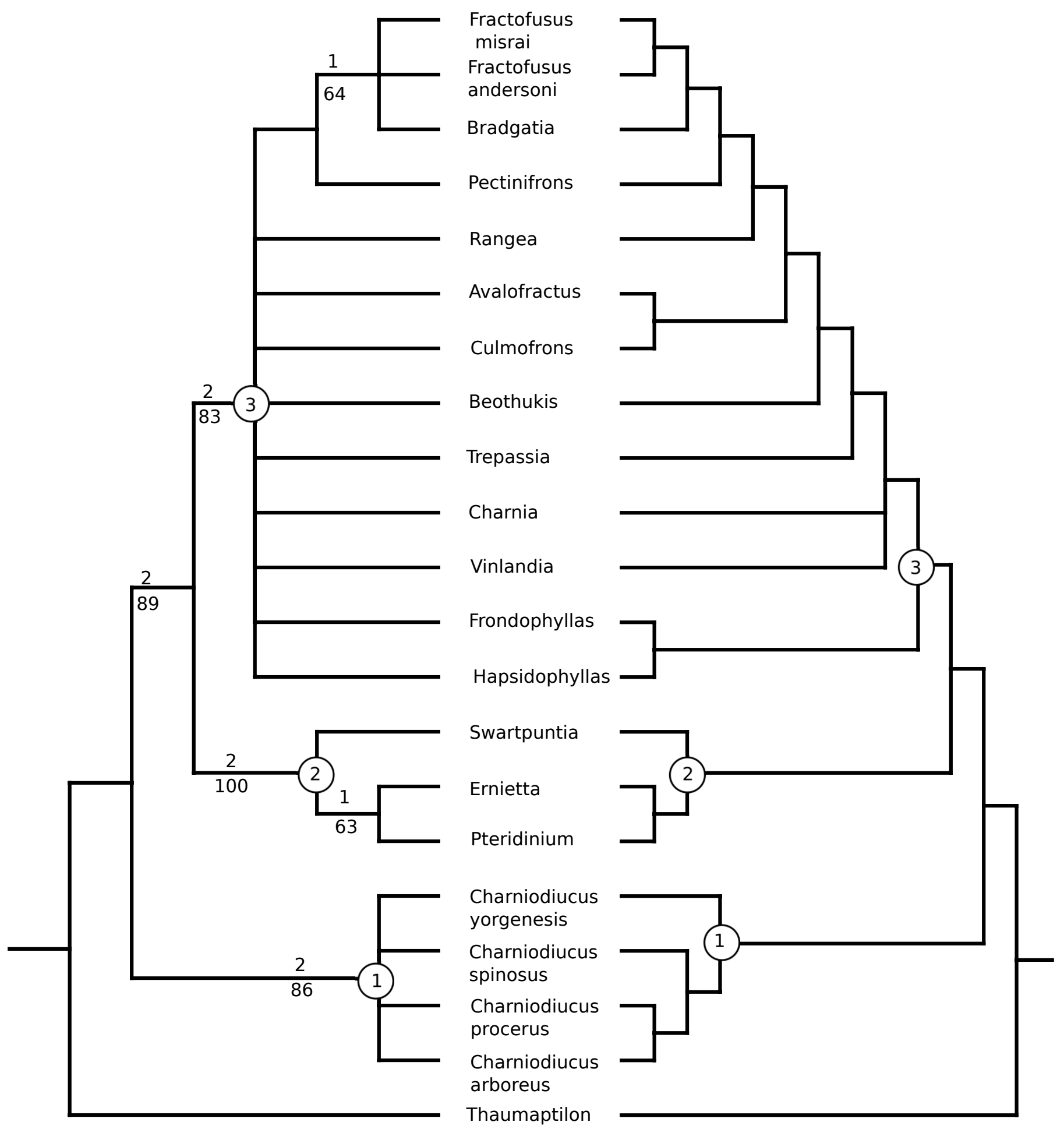

(1) Arboreomorpha

(2)Erniettomorpha

(3) Rangeomorpha

Figure 1 


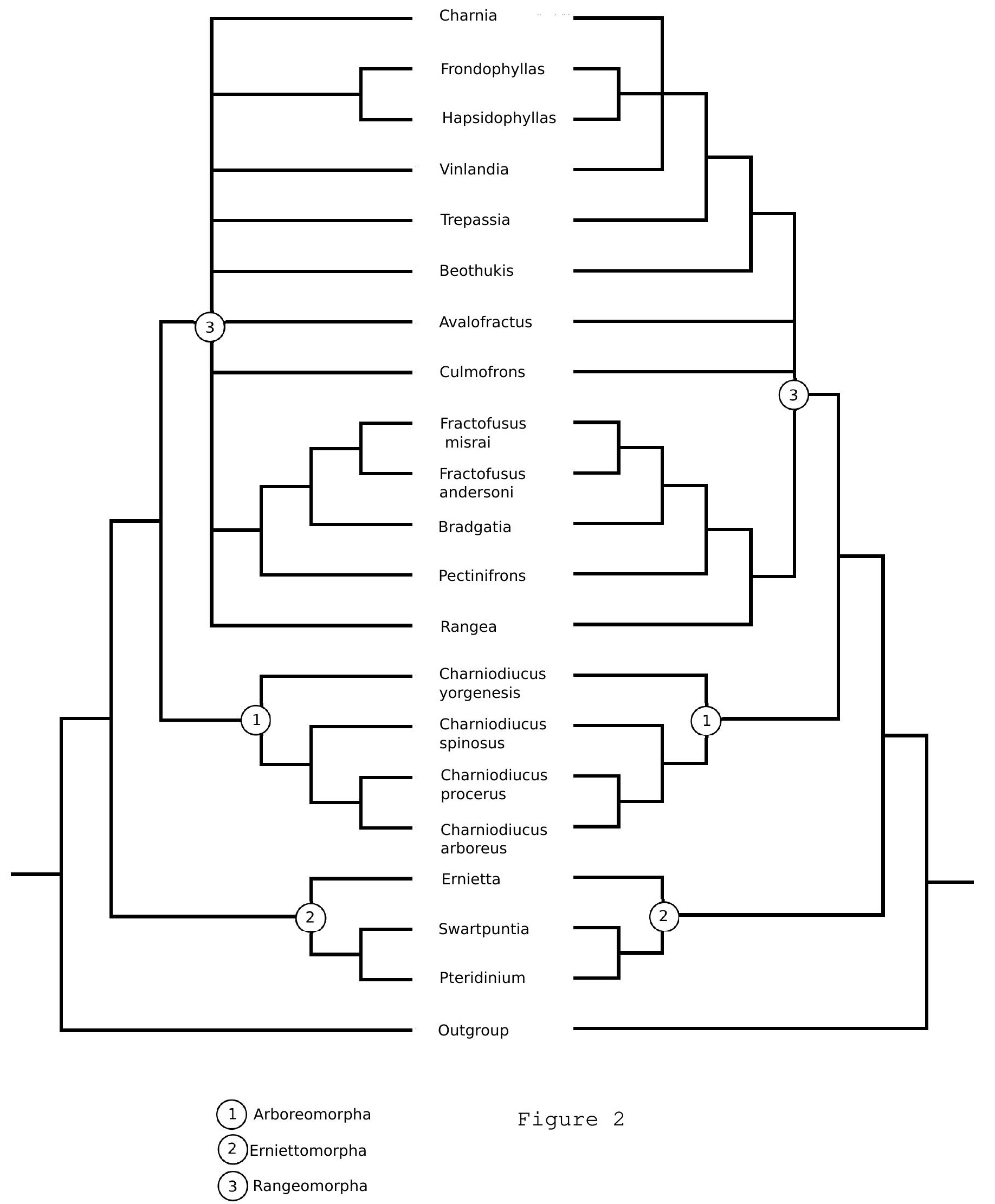


Table 1: Taxon list and preliminary group identification based on the literature for 21 terminal taxa examined for this study.

\begin{tabular}{|l|l|l|}
\hline Outgroup & Clade or Group & $\begin{array}{l}\text { Reference for } \\
\text { affiliation }\end{array}$ \\
\hline Thaumaptilon & Cnidaria & Conway Morris 1993 \\
\hline Ingroup & & \\
\hline Charnia & Rangeomorpha & Erwin et al. 2011 \\
\hline Beothukis & Rangeomorpha & Erwin et al. 2011 \\
\hline Vinlandia & Rangeomorpha & Brasier et al. 2012 \\
\hline Avalofractus & Rangeomorpha & Erwin et al. 2011 \\
\hline Culmofrons & Rangeomorpha & Erwin et al. 2011 \\
\hline Trepassia & Rangeomorpha & Erwin et al. 2011 \\
\hline Pectinifrons & Rangeomorpha & Erwin et al. 2011 \\
\hline Frondophyllas & Rangeomorpha & Erwin et al. 2011 \\
\hline Hapsidophyllas & Rangeomorpha & Erwin et al. 2011 \\
\hline Fractofusus andersoni & Rangeomorpha & Erwin et al. 2011 \\
\hline Fractofusus misrai & Rangeomorpha & Erwin et al. 2011 \\
\hline Bradgatia & Rangeomorpha & Erwin et al. 2011 \\
\hline Rangea & Rangeomorpha & Erwin et al. 2011 \\
\hline Ernietta & Erniettomorpha & Erwin et al. 2011 \\
\hline Pteridinium & Erniettomorpha & Erwin et al. 2011 \\
\hline Swartpuntia & Erniettomorpha & Erwin et al. 2011 \\
\hline Charniodiscus spinosus & Arboreomorpha & Erwin et al. 2011 \\
\hline Charniodiscus procerus & Arboreomorpha & Erwin et al. 2011 \\
\hline Charniodiscus arboreus & Arboreomorpha & Erwin et al. 2011 \\
\hline Charniodiscus yorgenesis & Arboreomorpha & Ivantsov 2016 \\
\hline
\end{tabular}


Table 2: Synapomorphies listed in terms of character (state) for the three major clades using both Thaumaptilion (A) and artificially generated outgroup (B) analyses. We should note the difference between unambiguous and ambiguous synapomorphies is dependant on the resolution of the node preceding that of interest. As selection of outgroup alters the sister clade relationships (see Figure 1 and 2) we suggest using only the unambiguous synapomorphies list is an overly conservative estimate of the number of apomorphies per clade.

\begin{tabular}{|l|l|l|l|}
\hline & Clade & $\begin{array}{l}\text { Unambiguous } \\
\text { synapomorphy }\end{array}$ & $\begin{array}{l}\text { Ambiguous } \\
\text { synapormorphy }\end{array}$ \\
\hline A) & Arboreomorpha & $8(3), 11(3)$, & $22(2)$ \\
\cline { 2 - 4 } & Erniettomorpha & $\begin{array}{l}3(1), 5(0), 13(2), \\
14(0),\end{array}$ & $2(0), 4(1)$ \\
\cline { 2 - 4 } & Rangeomorpha & $8(2), 15(0), 18(0)$ & $2(1), 4(2), 13(1)$ \\
\hline B) & Arboreomorpha & $9(1), 19(1)$ & $\begin{array}{l}1(0), 4(0), 8(3), \\
22(2)\end{array}$ \\
\cline { 2 - 4 } & Erniettomorpha & $11(0)$ & $3(1), 4(1)$ \\
\cline { 2 - 4 } & Rangeomorpha & $\begin{array}{l}11(1), 15(0), \\
18(0)\end{array}$ & $2(1), 4(2), 8(2)$ \\
& &
\end{tabular}


Supplementary Table 1: Character list.

1. Petalodium or main body of organism formed primarily of repeating, modular elements

0 absent

1 present

2. Petalodium or main body of organism formed primarily of repeating, modular elements

0 non branching

1 branching

3. Elements that compose petalodium are

0 non-tubular

1 tubular

4. Elements that compose petalodium are

0 non-fractal, no divisions lower than primary

1 non-fractal, structure that repeats along the primary but is distinct from

primary's gross morphology, terminating so as no lower size divisions ("tertiaries")

2 fractal

5. Organism is composed primarily of

0 undifferentiated, single type of element regardless of location on organism, no subdivision or sub branching

1 Differentiated structures, either by branching, or regional differential of tissue

6. Petaloidum number:

0 single petalodium

1 multipletalodums each with a separate stalk or other division

7. Petaloid number (definition from Laflamme and Narbonne 2008)

02 petaloids, often but not always, creating a flat, single plane

1 Multiple petaloids that are symmetrically arranged

8. Primary branches display branching pattern of "secondaries" rows (see Figure 3 in Laflamme et al. 2012), this arrangement is:

0 primaries show no subdivisions

1 rows displaying double-sided morphology

2 row displaying single sided morphology

3 branches display structures that are spherical or hemi-spherical in shape, may not be in rows 
9. Branches differentiated in coronal plane (dorsal /ventral plane of Jenkins and Gehling 1978):

0 absent, both sides in coronal aspect show equivalent structural complexity 1 present, one side shows significantly reduced or absent of structural features.

10. Presence of subsidiary frondlets (as per Gehling and Narbonne 2007)

0 absent

1 present

11. Secondary branches display branching pattern of "tertiaries" rows (see Figure 3 in Laflamme et al. 2012), this arrangement is

0 secondaries not present or show no subdivisions

1 double sided

2 single sided

12. Growth pattern of new primaries

0 Insertion

1 Inflation

2 Insertion then inflation

13. Branching of higher-level elements (secondary, tertiary etc.):

0 only 1 level of branching

1 parallel to sub-parallel to the element 1 level up

2 perpendicular to the element 1 level up

14. Primary branches

0 same width throughout

1 variable width

15. Primary branch width based on largest central branches

0 distal contraction

1 Distal expansion

2 uniform

16. Polarity (the number of apical growth tips within a single frondose organism):

0 unipolar

1 bipolar

2 multipolar

17. Central stalk/ commissure:

0 absent, apparent stalk is product of element bifurcation pattern or thickening of tissue where elements overlap

1 present 
18. Stalk, if present

0 internal

1 external

19. Stalk prominence

0 thin

1 thick (similar to stem in width)

20. Stem

0 absent/ minor, $<5 \%$ total frond length

1 present $>5 \%$ but less than $20 \%$

$2>20 \%$

21. The presence of a distinct region anchoring the organism to the sediment including internal anchors as seen in Rangea (Vickers-Rich et al. 2013) and true holdfasts.

0 absent, no distinct region present,

1 present

22. Holdfast position (See Burzynski and Narbonne 2015 in relation to the sediment water interface and a larger discussion on differentiation this feature)

0 absent

1 present, subsurface

2 present- surficial

\section{References}

Burzynski, G. and G.M. Narbonne, 2015. The discs of Avalon discoid fossils to frondose organisms in the Ediacaran of Newfoundland, Canada. Palaeogeography, Palaeoclimatology, Palaeoecology, 434: 34-45.

Gehling, J.G., and G.M. Narbonne. 2007. Spindle-shaped Ediacara fossils from the Mistaken Point assemblage, Avalon Zone, Newfoundland. Canadian Journal of Earth Sciences 44(3):367-387.

Jenkins and Gehling 1978. A review of Frond-like fossils of the Ediacaran assembledge. Records fo the South Australia Museum. 17(23): 347-359.

Laflamme, M., L. Flude, and G. Narbonne. 2012. Ecological tiering and the evolution of a stem: The oldest stemmed frond from the Ediacaran of Newfoundland, Canada. Journal of Paleontology 86(2):193-200.

Laflamme, M., and G. Narbonne. 2008. Ediacaran fronds. Palaeogeography Palaeoclimatology Palaeoecology 258(3):162-179. 
Vickers-Rich, P., A. Y. Ivantsov, P. Trusler, G.M.Narbonne, M.Hall, S.A.Wilson, C.Greentree, M.A. Fedonkin, D.A.Elliott, K.H.Hoffmann and G.I.C. Schneider. 2013. Reconstructing Rangea: New discoveries from the Ediacaran of southern Nambia. Journal of Paleontology 87(1):1-15. 


\begin{tabular}{|c|c|c|c|c|c|c|c|c|c|c|c|c|c|c|c|c|c|c|c|c|c|c|}
\hline & 1 & 2 & 3 & 4 & 5 & 6 & 7 & 8 & 9 & $\begin{array}{l}1 \\
0\end{array}$ & $\begin{array}{l}1 \\
1\end{array}$ & $\begin{array}{l}1 \\
2\end{array}$ & $\begin{array}{l}1 \\
3\end{array}$ & $\begin{array}{l}1 \\
4\end{array}$ & $\begin{array}{l}1 \\
5\end{array}$ & $\begin{array}{l}1 \\
6\end{array}$ & $\begin{array}{l}1 \\
7\end{array}$ & $\begin{array}{l}1 \\
8\end{array}$ & $\begin{array}{l}1 \\
9\end{array}$ & $\begin{array}{l}2 \\
0\end{array}$ & $\begin{array}{l}2 \\
1\end{array}$ & $\begin{array}{l}2 \\
2\end{array}$ \\
\hline $\begin{array}{l}\text { Artificial } \\
\text { Outgroup }\end{array}$ & 0 & - & - & - & 0 & 0 & 0 & 0 & 0 & 0 & 0 & $?$ & 0 & 0 & 2 & 0 & 0 & $?$ & $?$ & 0 & 0 & 0 \\
\hline Thaumaptilon & 0 & - & 0 & 1 & 1 & 0 & 0 & 0 & 1 & 0 & 0 & 0 & 0 & 1 & 2 & 0 & 1 & 1 & 1 & 0 & 1 & 1 \\
\hline Charnia & 1 & 1 & 0 & 2 & 1 & 0 & 0 & 2 & 0 & 0 & 2 & 0 & 2 & 1 & 0 & 0 & 1 & 0 & 0 & 0 & 1 & 1 \\
\hline Beothukis & 1 & 1 & 0 & 2 & 1 & 0 & 0 & 2 & 0 & 0 & 1 & 1 & 1 & 1 & 0 & 0 & 1 & 0 & 0 & 0 & 1 & 1 \\
\hline Vinlandia & 1 & 1 & 0 & 2 & 1 & 0 & 0 & 2 & 0 & 0 & 2 & $?$ & 2 & 1 & 0 & 0 & 1 & 0 & 0 & 0 & 1 & 1 \\
\hline Avalofractus & 1 & 1 & 0 & 2 & 1 & 0 & 0 & 1 & 0 & 0 & 1 & 1 & 1 & 1 & 0 & 0 & 1 & 0 & 0 & 2 & 1 & 2 \\
\hline Culmofrons & 1 & 1 & 0 & 2 & 1 & 0 & 0 & 2 & 0 & 0 & 1 & 1 & 1 & 1 & 0 & 0 & 1 & 0 & 0 & 2 & 1 & 2 \\
\hline Trepassia & 1 & 1 & 0 & 2 & 1 & 0 & 0 & 2 & 0 & 0 & 2 & 0 & 1 & 1 & 0 & 0 & 1 & 0 & 0 & 0 & 1 & 1 \\
\hline Pectinifrons & 1 & 1 & 0 & 2 & 1 & 1 & 0 & $?$ & 0 & 0 & $?$ & 2 & $?$ & 1 & 1 & 2 & 1 & 0 & 0 & 0 & 1 & 2 \\
\hline Frondophyllas & 1 & 1 & 0 & 2 & 1 & 0 & 0 & 2 & 0 & 0 & 2 & $?$ & 2 & 1 & 0 & 0 & 1 & 1 & 0 & 0 & $?$ & $?$ \\
\hline Hapsidophyllas & 1 & 1 & 0 & 2 & 1 & 1 & 0 & 2 & 0 & 0 & 2 & $?$ & 2 & 1 & 0 & 2 & 1 & 1 & 0 & 0 & 1 & 2 \\
\hline $\begin{array}{l}\text { Fractofusus } \\
\text { andersoni }\end{array}$ & 1 & 1 & 0 & 2 & 1 & 0 & 0 & 1 & 0 & 0 & 1 & 1 & 1 & 1 & 1 & 1 & 0 & - & - & 0 & 0 & - \\
\hline Fr. misrai & 1 & 1 & 0 & 2 & 1 & 0 & 0 & 1 & 0 & 1 & 1 & 1 & 1 & 1 & 1 & 1 & 0 & - & - & 0 & 0 & - \\
\hline Bradgatia & 1 & 1 & 0 & 2 & 1 & 1 & 0 & 1 & 0 & 0 & 1 & 1 & 1 & 1 & 1 & 2 & 0 & - & - & 0 & 0 & - \\
\hline Rangea & 1 & 1 & 0 & 2 & 1 & 0 & 1 & 1 & 0 & 1 & 1 & $?$ & 1 & 1 & 1 & 0 & 1 & 0 & 0 & 0 & 1 & 0 \\
\hline Ernietta & 1 & 0 & 1 & 0 & 0 & 0 & 0 & 0 & 0 & 0 & 0 & 1 & 0 & 0 & 2 & 0 & 0 & - & - & 0 & 0 & - \\
\hline Pteridinium & 1 & 0 & 1 & 0 & 0 & 0 & 1 & 0 & 0 & 0 & 0 & 0 & 0 & 0 & 2 & 0 & 0 & - & - & 0 & 0 & - \\
\hline Swartpuntia & 1 & 0 & 1 & 0 & 0 & 0 & 1 & 0 & 0 & 0 & 0 & $?$ & 0 & 0 & 2 & 0 & 1 & 1 & 0 & $?$ & $?$ & $?$ \\
\hline Ch. spinosus & 0 & - & 0 & 1 & 1 & 0 & 0 & 3 & $?$ & 0 & $?$ & 1 & 1 & 1 & 2 & 0 & 1 & 1 & 1 & 1 & 1 & 2 \\
\hline Ch. procerus & 0 & - & 0 & 1 & 1 & 0 & 0 & 3 & $?$ & 0 & $?$ & 1 & 2 & 1 & 2 & 0 & 1 & 1 & 1 & 2 & 1 & 2 \\
\hline Ch. arboreus & 0 & - & 0 & 1 & 1 & 0 & 0 & 3 & 1 & 0 & 0 & 1 & 2 & 1 & 2 & 0 & 1 & 1 & 1 & 1 & 1 & 2 \\
\hline Ch. yorgenesis & 0 & - & 0 & 1 & 1 & 0 & 0 & 3 & 1 & 0 & 0 & 1 & 1 & 1 & 2 & 0 & 1 & 1 & 1 & 0 & 1 & 2 \\
\hline
\end{tabular}


A

A)

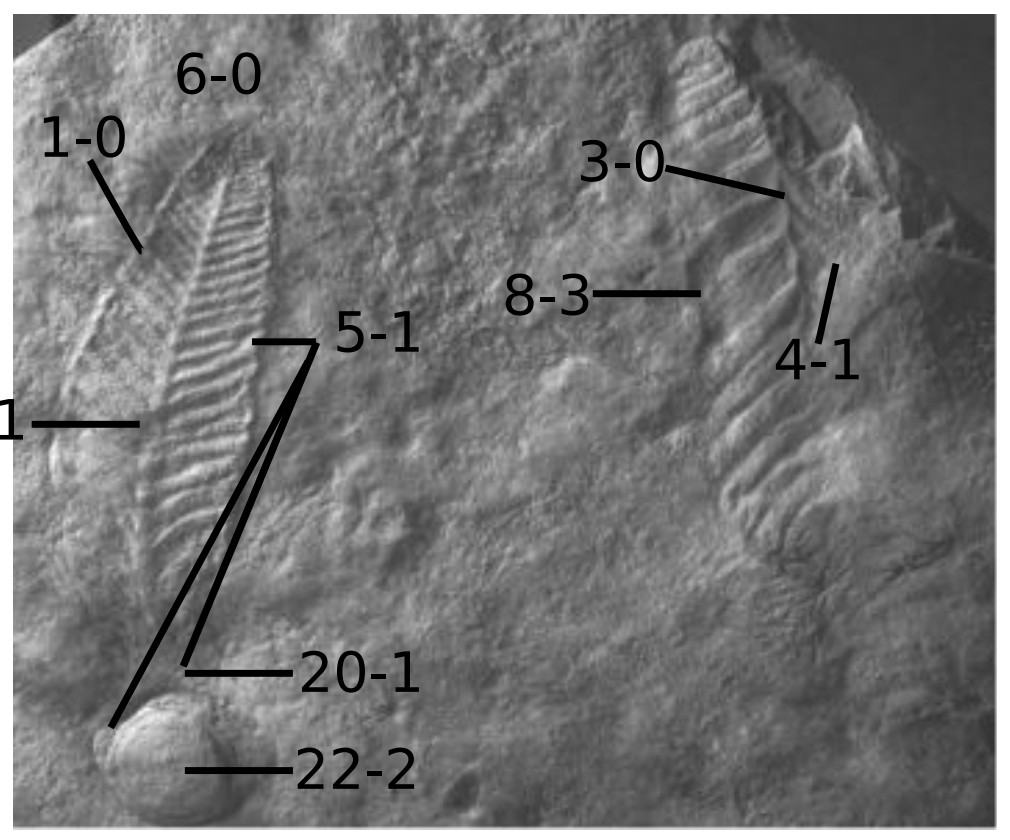

C)

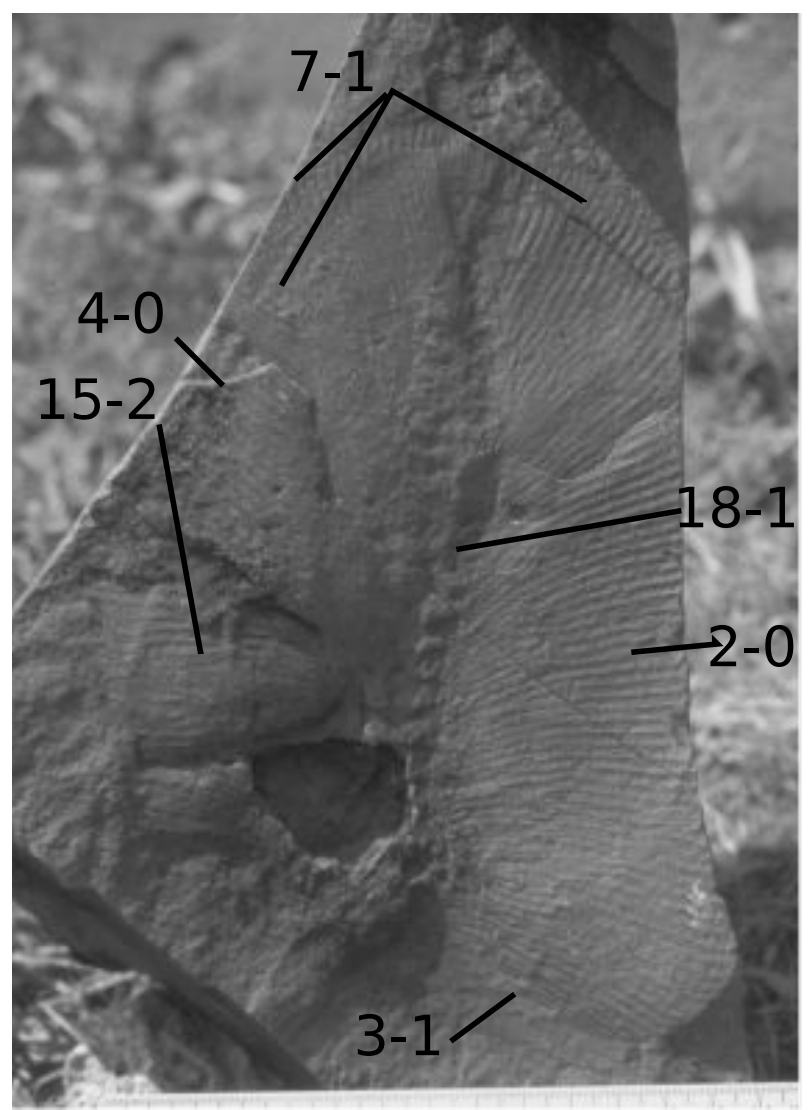

E)

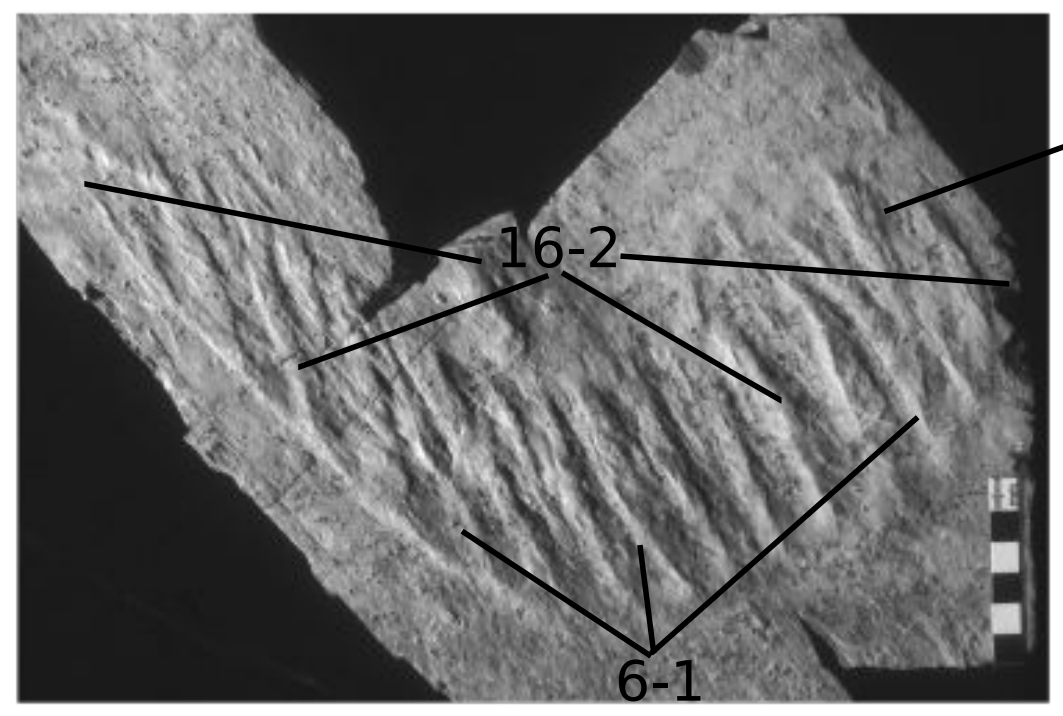

B)

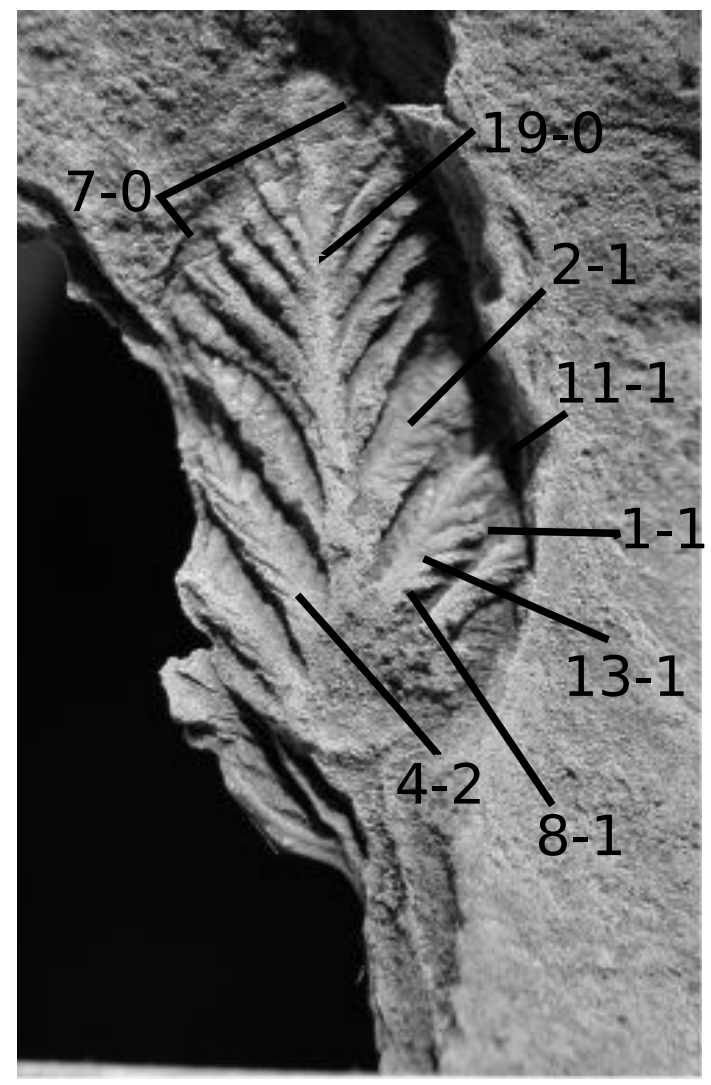

D)

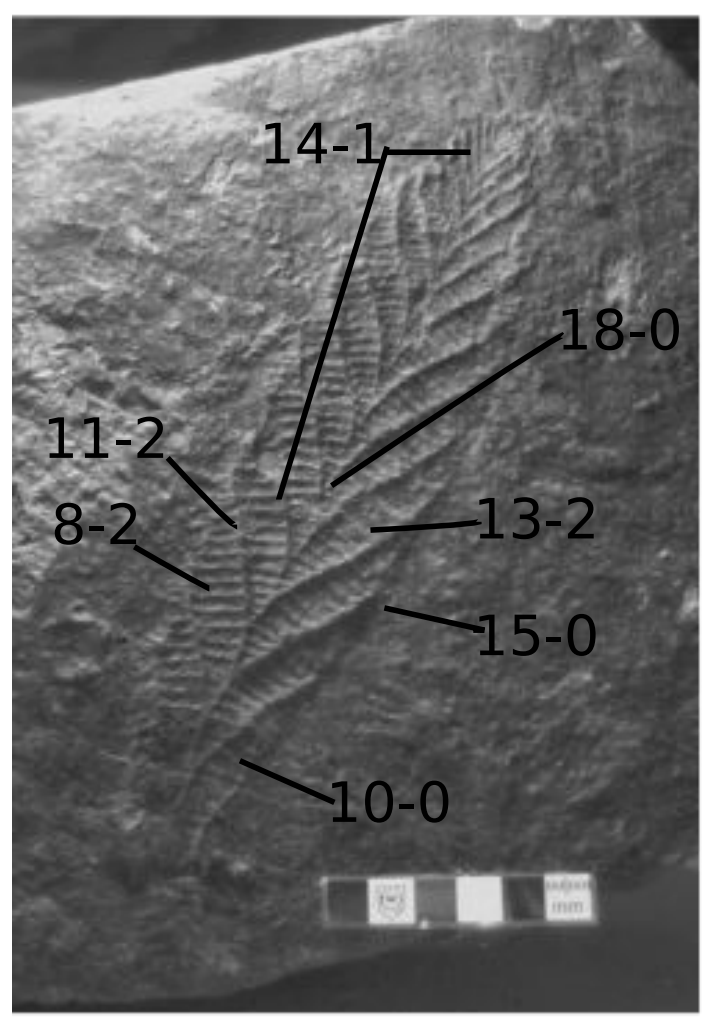

2-1

Supplementary Figure 1 
F)

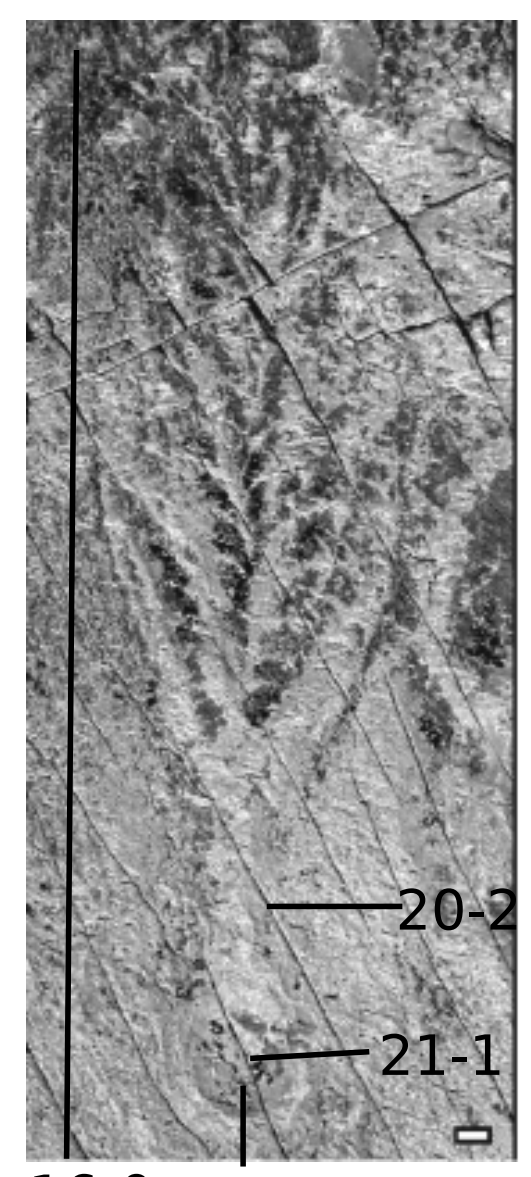

16-0 22-2

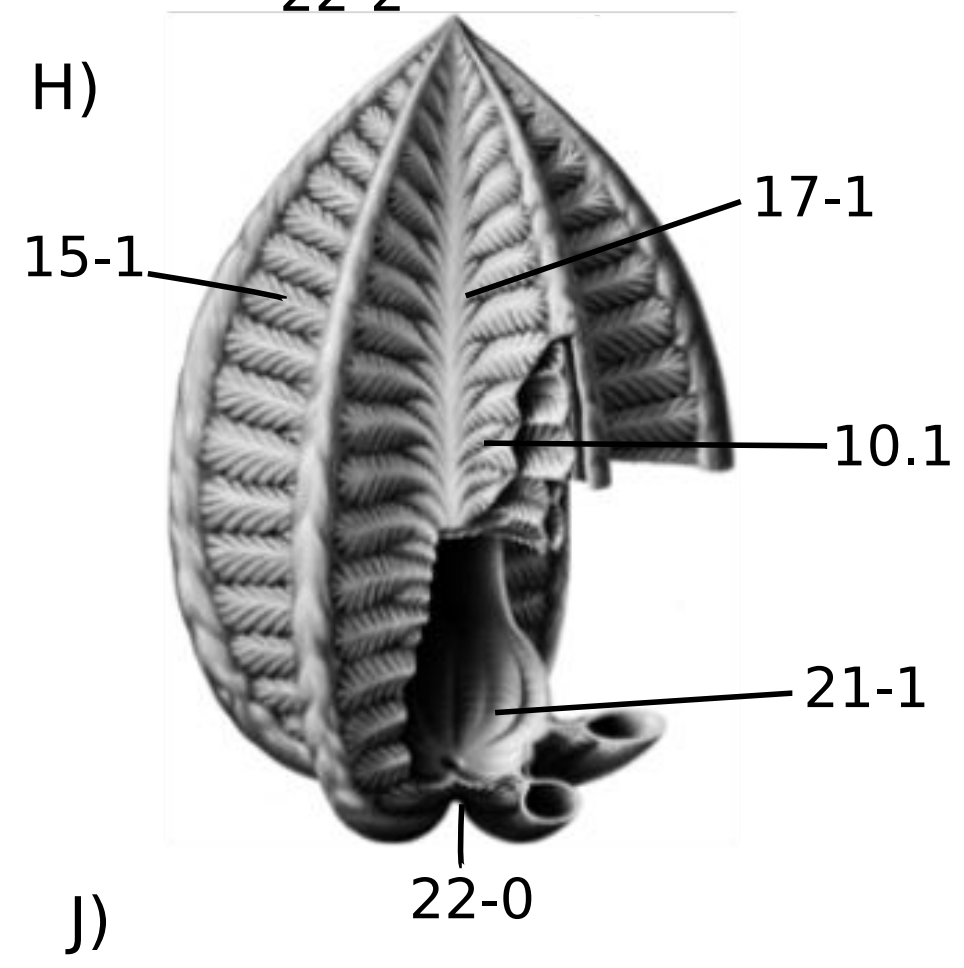

21-0

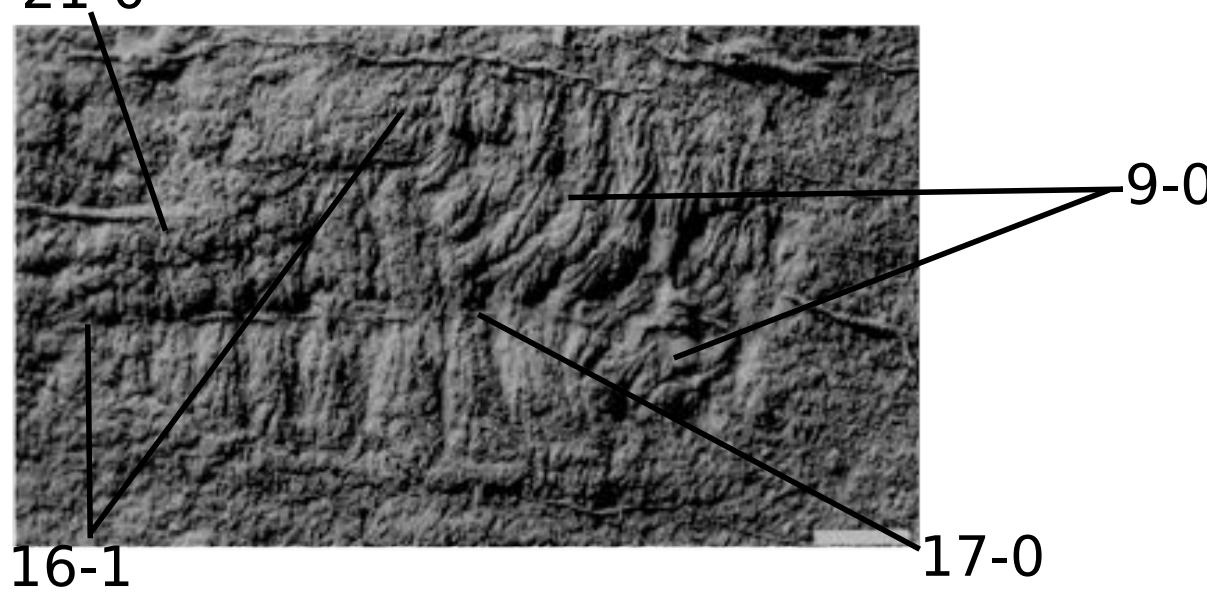

G)
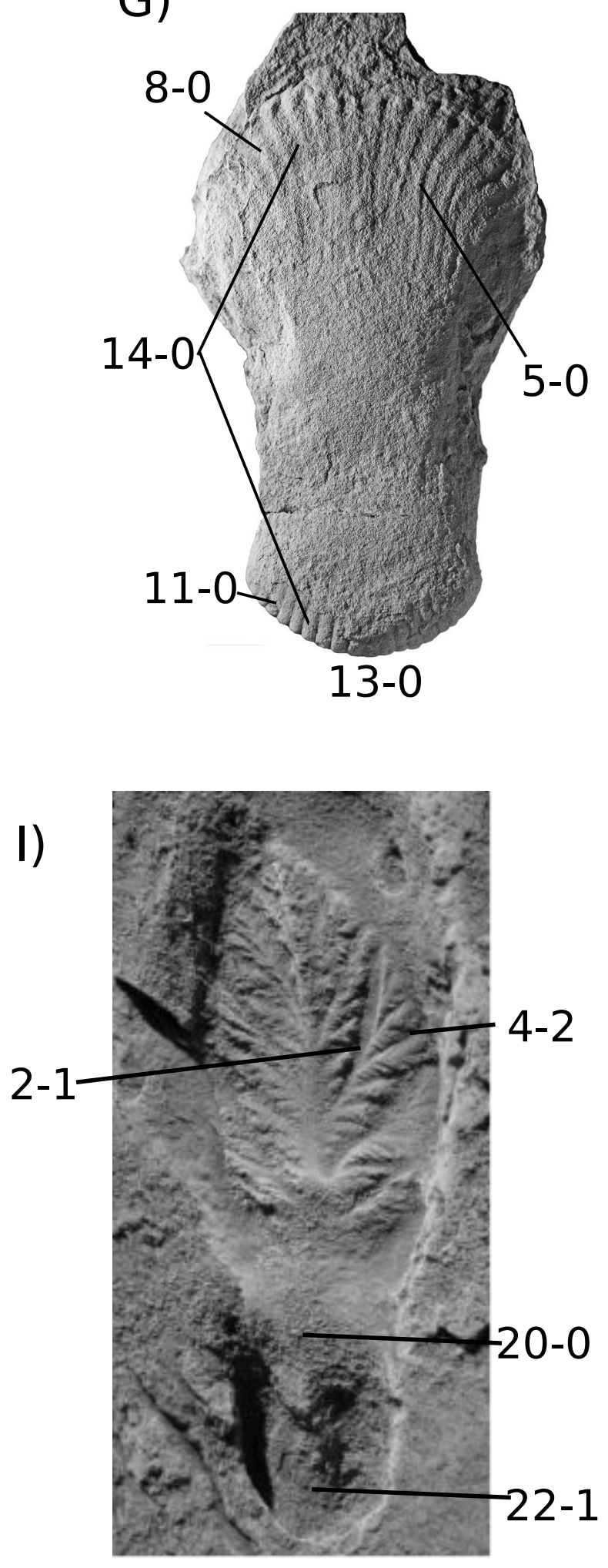

K) 